\title{
Type III Acrocephalosyndactyly
}

National Cancer Institute

\section{Source}

National Cancer Institute. Type III Acrocephalosyndactyly. NCI Thesaurus. Code C75034.

A rare autosomal dominant syndrome caused by mutations in the TWIST 1 gene. It is characterized by premature closure of skull bones resulting in abnormally shaped head, high forehead, hypertelorism, and facial asymmetry. It may be associated with fusion of certain fingers or toes. 